\title{
Awareness-raising Process on Present Popular and Life Culture and Aesthetic Perceptions through the Kitsch Phenomenon
}

\author{
Ferda Ozturk Komleksiz \\ Faculty of Education, European University of Lefke, Lefke, 99800, Turkish Republic of Northern Cyprus, Mersin 10, Turkey
}

Copyright $(2018$ by authors, all rights reserved. Authors agree that this article remains permanently open access under the terms of the Creative Commons Attribution License 4.0 International License

\begin{abstract}
The purpose of the study is to explore the views of students enrolled at pre-school teaching department regarding kitsch phenomenon handled within scope of "Creativity and Its Development" and "Drama" courses in the context of creativity, mimesis and devolution. This study was designed as a qualitative study and conducted with 38 students selected among 108 sophomore students enrolled in "Creativity and Its Development" course and in the spring semester with the same students enrolled in "Drama". In both courses, kitsch phenomenon was the main focus of the study and the activities were carried out with the students on kitsch phenomenon. After all these activities were implemented in the courses, students' views on kitsch phenomenon were obtained by face to face interviews. Finding showed that motivation and moral values of students can be increased by conducting different artistic works in university courses such as creativity and its improvement and drama in pre-school teaching departments. Furthermore, the studies conducted on the "kitsch" phenomenon to increase awareness related to creativity was effective in understanding and internalizing creativity.
\end{abstract}

Keywords Creativity, Drama Education, Art Education, Pre-school Teaching, Kitsch

\section{Introduction}

Kitsch phenomenon appears in several forms as a concept which surrounds our environment in this era.

Şahin [1] assessed kitsch as a concept that indicates objects without artistic value, which can be bought for low prices and are adapted to the general level of appreciation, is an extension of capitalist order. It is seen that in culturally inadequate and industrialized societies, kitsch can reproduce faster, and in periods when cultural, economic, political and artistic life passes through different stages, it finds itself suitable environments for reproduction. Fisher and Williams [2] interprets this situation as "artist found himself in a strange situation in the capitalist era. King Midas turned everything he touched into gold; capitalism turned everything into commodity". Özdemir and Koca [3] argue that capitalism exceeded all class differences in order to include people of every class the marketplace has created by capitalism through presenting a common lifestyle and culture called "popular culture". Baudrilland [4] says that the industrial proliferation of distinctive indicators borrowed from a plethora of directions (past, new, exotic, folkloric, futurist), their vulgarisation, and irregular increase of "ready-to-use" indicators led to the increase of kitsch whose foundations can be found in the sociological reality of the consumption society exemplified by "mass culture".

Ergin, Halhallı [5] claims that kitsch deceives masses through an exaggerated emotionality by hiding behind mimesis. Baudrilland [4] defines kitsch as so-called object, meaning simulation, copied, counterfeit, stereotyped object, lack of real sense-making and indication, allegoric references, plethora of incompatible side-meanings, aggrandizing of details and satisfaction through details. A general overview shows that the concept of "mimesis" which is identified with the kitsch phenomenon appears from the antique ages as a concept which is contemplated over and interpreted in different ways. While discussing the difference between mimesis understandings of Plato and Aristotle, Tunalı [6] claims that according to Aristotle human is an imitating being, but for Aristotle mimesis is not just imitation like in Platon, and an unnecessary activity based on copying the nature especially in artistic terms. Şaylan [7] claims that today's modernist art and aesthetic understanding is a criterion of uniqueness and creativity, that mimesis is denied in postmodern discourse which appeared in 1960s, postmodern artists were not against mimesis (kitsch). Kulka [8] argues that although 
postmodernism used kitsch and makes references to it just like Pop Art, it did not produce kitsch, and unlike kitsch postmodern works usually required interpretation, and neither Pop Art nor Postmodernism means that we have to restore the artistic honour of kitsch. Kulka [8] emphasizes the sociological aspect of the subject by stating that kitsch is a part of modern culture without debate, regardless of whether it entered our lives recently or it has a history as old as art itself, and today it became widespread at an unprecedented scale. Erinç [9] examines the subject from the point of art sociology and emphasises the importance of preserving urban art from the point of social structure. He claims otherwise cities would be equipped with small town aesthetic, and that kitsch art (in Erinç's words "ratty art") emerged in that manner. Berk [10] raises an objection to perceiving public taste as kitsch or vulgarism and tells "it is essential to separate kitsch from vulgarism and examine the place of the concept of vulgarism in history". Thus, he emphasises that kitsch is an artificial cultural invention which was invented in order to weaken the resistance awareness of masses by calculating their measures of liking. Ove, Tuv [11] claims that the concept "kitsch" is the subject of bad taste and sociological studies and everything can be collected under the title of this concept including plastic tulips, painted small ceramic sculptures, and badly drawn crying child pictures. As regards crying child pictures, Kulka [8] says "the eyes of the child in kitsch pictures is non-proportionally big, the teardrops he sheds are five times the size of a real teardrops" and emphasises the standard, traditional, repetitive retesting of kitsch which ignores details. Ilkyaz [12] argues that as long as the tragedy of human continues, the struggle between shallow, vulgar kitsch products and real works of art will go on. Güven [13] stresses that while distinguishing kitsch from art it is necessary to display their difference in terms of shape and content instead of using clear expressions. For this reason, although kitsch phenomenon is defined as a lower-class culture and degenerated liking, the "kitsch" reality of our age has to be evaluated based on different dimensions.

When the concept of kitsch is mentioned what comes to the mind is mimesis; in the same vein, when the concept of creativity is mentioned, we think of staying away from the element of mimesis. Then why do we imitate? Why does the element of mimesis occupy such an important place in our lives? Why is it so difficult to produce different ways of solution? The answer to these questions is usually that mimesis is easy and does not require much thinking. For this reason, mimesis occupies its place in the literature as a concept which requires careful elaboration especially starting from childhood period. Akçum [14] emphasizes the importance of mimesis in the development of creativity in childhood period. As Akçum stated, we are experiencing first learning through mimesis, but the fact that mimesis is a facto which prevents creativity, which constitutes an irony. Creativity is the state of being self and no one else. For this reason, if identical imitation becomes our life style and our power of imagination weakens in one way or other, and if do not have any encounters with artistic stimulants, give priority to aesthetic concerns, ask questions, produce ideas, be a captive of root learning system, we become distant from creativity, become ordinary and monotype. Fisher and Williams [2] defines creativity as a concretized power of imagination, imaginary action and the process of producing an imaginary action and an original thing. $\mathrm{He}$ gives the example of the expression of a 10-year-old child, Miercoles, stating "creativity is like imaginary power, in order to create something, we have to imagine it first" as a support of this definition.

Akçum [14] argues that today's education system is restrained or proves insufficient as regards developing creative thinking abilities by curricula, physical facilities and attitudes of teachers and administrators. For that reason, he emphasises the importance of preparing future-oriented curriculums which adapt to changing conditions and needs, innovate themselves, provide information as required by preparedness in basic education, aiming ad raising students as creative, asking-questioning people who attempt to find solutions to problems. Although authorities accept the importance of raising creative individuals and we have more theoretic knowledge about creativity today, it is clear that applications conducted regarding creativity are far from being adequate (Fisher and Williams [2] ; Craft [15]; Kalburan [16]; Kırışoğlu [17]). In this context, it can be said that activating the creative power that we accept as existing more or less in every human being can only be possible with appropriate education environments. Terwiel, Dizdar [18] remark that one of the topics that requires attention while determining the goals of pre-school education is to make sure that the child becomes aware of different branches of art through art education. Sebik [19] argues that the creativity of a child who contacts with kitsch structures will be impeded, who will move away from creative thinking which results in the formation of a personality characterised by perceptual laziness, lack of questioning, and general passivation. He states that children who are educated with acquisitions involving kitsch liking can lead to artistic disability at micro level and colour-blindness for reality at macro level. For these reasons, it must be considered that works conducted with the purpose of improving creativity turn into kitsch when they do not have any aesthetic concern. This can be prevented only through an arts education clarified from kitsch concept. It can be said that the major responsibility belongs to educators at this point.

Çankaya, Yeşilyurt, Yörük and Önder [20] emphasise that teachers have to have such qualifications as creative thinking, openness to change, imaginary power to train their students to acquire these desired qualities. Gökalp 
[21] says "educators must guide children in using their creativity characteristics" and stresses that traditional stereotype programmes and methods turn children into individuals who think uniformly, are copied from each other, and unable to produce anything. Terwiel, Dizdar [18] conducted an experimental study on pre-school children and argued that memorized habits and inclination towards drawing can be observed in every child. Yılmaz [22] claims that when one enters the school areas where the works of children are exhibited, he/she sees tens of works in the halls which are almost identical. These template works which are created by using shapes, colours and materials which are similar to each other prepared by cutting by teachers in the form of a mould are not only killing the creativity of children but also destroying their self-confidence in time. This situation accustoms the child to laggardness and removes him/her from aesthetic concerns and makes them monotypic. This understanding in education is also reflected to the school performances which are far from creativity. In such an environment full of mimetic elements, it is not possible to keep the children outside the kitsch phenomenon.

Lugg [23] claims that what makes kitsch "kitsch" is that it is simple and predictable. Baudrilland (2016) says that the industrial proliferation of distinctive indicators borrowed from a plethora of directions (past, new, exotic, folkloric, futurist), their vulgarization, and irregular increase of "ready-to-use" indicators led to the increase of kitsch whose foundations can be found in the sociological reality of the consumption society exemplified by "mass culture". This structure of kitsch also includes the young people into this circle. It is essential that young people studying pedagogy at universities are aware of kitsch elements so that they can internalize the concept of creativity. Mamur [24] conducted a research with university students and emphasised that courses should be designed in a wat that teacher candidates acquire the ability to elaborate on and criticize art and develop their aesthetic sensitivity. He also suggests that arts education is inevitable from the first to the last stage of education so that man can understand himself and the society he is living in. Dikici [25] argues that the greatest task in the development of the students' creativity lays in the attitudes and behaviours of teachers towards their students.

When the studies related to kitsch in the literature are examined, it can be seen that although some studies were conducted on kitsch phenomenon they were mostly in the field of modernism, postmodernism and plastic arts. There were no study on the view of students at education faculty which did not receive general education on art as regards their aesthetic development and awareness and opinions on kitsch phenomenon in the context of creativity, mimesis and degeneration. It is essential that undergraduate curricula of education faculties include such courses as "creativity and its development", "arts education", and "drama" and that these courses should be delivered by people specialised in these fields through applications which prioritize creativity. It is seen that drama courses in undergraduate curricula of education faculties positively affect the attitudes and behaviours as well as creativity of teachers. Akar Vural and Somers [26] emphasize that drama is one of the main instruments that can help the teacher in creating a learning-teaching process which is meaningful, permanent and interrelated with life, and that an individual who is able to notice and interpret dramatic situations and its circumstances can improve himself in interpreting life situations. Working on different concepts at teacher educating institutions which can create artistic awareness and giving more space to concepts such as kitsch which can stimulate aesthetic perceptions can ensure that teacher candidates are moved away from mimetic template works. For this reason, this study attempts to document the opinions of students at pre-school teaching department on the "kitsch" phenomenon which is addressed within the scope of "creativity and its development" and "drama" courses in the context of creativity, mimesis and degeneration and to raise an awareness as regards today's popular and life culture and aesthetic understanding.

\section{Method}

\subsection{Design}

This study is a qualitative study conducted on sophomore students at pre-school teaching department who enrolled in "development of creativity" class in 2015-2016 fall semesters and "drama" class in spring semester. In both classes kitsch phenomenon was covered when necessary and students were carried out activities on kitsch. Below are the activities implemented in both courses:

1) At the beginning of the study students were asked to prepare a creative object or a formation before conducting any study on kitsch phenomenon. This study was conducted in order to determine the initial views of students about the concept of creativity before they started to work on kitsch concept.

2) Later, students examined the kitsches around them so as to make more sense of "kitsch" phenomenon which they examine and study in their environment in "creativity and its development" course. Through this examination, they try to internalize the concept. The examined kitsches are related to fashion, architecture, external decoration, house furniture, jewellery, accessories, signboards, superstitions and attitudes. Fifteen exhibition materials were prepared as regards the kitsches related to these themes which were "superstition chest", a lampshade titled "girl with skirt", a snail-shaped box, a shoe-shaped box, kitsch house 
model, nail catalogue, gift package box, jewellery box, curtain box, fashion magazine titled "Kilık", kitsch kindergarten model, a fashion magazine in the shape of bag, a fashion magazine titled "Kiço" and a child photograph album. Three groups studied attitude kitsches for which reason they prepared 3 videos themed "Crazy boy Iso", "Teen room" and "Neighbourhood" which emphasised superstitious beliefs.

3) In kitsch video preparation activity, student worked as a group of maximum 5 members and prepared a photograph archive on the topics they studied through their themes. During the classroom implementations, they discussed whether the kitsches they thought they found were really kitsches. After the sharing their ideas, students prepared a selection from their study and prepared short kitsch videos about their themes. Some groups preferred to explain their selection through videos which were prepared based on a scenario that they themselves took part in. These videos included the kitsches they investigated and took pictures of. Students finally prepared portfolios related to their studies within the creativity project.

4) The study continued with the same student group who took "Drama" course in spring semester. Students who took "drama" course in the second semester identified "kitsch characters" for themselves based on "why" questions. These characters were created using such techniques as improvisation, role playing, letters, flashbacks, hot chair, dramatization etc. Each student was given the task of writing a text about his/her character. In the improvisation projects that students prepared, they determined kitsch problem situations based on the kitsch characters they created. In these improvisations, kitsch situations that we encounter in such areas as wedding, asking for the girl's hand in marriage, bus travel, family relations etc. were covered. The 12 kitsches which emerged in drama course were recorded to video without editing. The 108 students who participated in the study watched the improvisations which were recorded to the video without editing at the movie hall of the university with the participation of students. The students voted democratically for the 3 improvisations which would be included in year-end performance after watching their improvisations.

5) The studies which were planned as two semesters were presented to the audience in the conference hall of the university at the end of $2^{\text {nd }}$ semester (year-end) as a performance work. Before the performance the viewers were welcomed with an exhibition consisting of kitsch photographs and kitsch objects. The profile photographs in the photograph exhibition were kitsch characters created by all students who performed the study. The exhibition was organized as a reference to sharing "everything" in social network sites. The viewers were welcomed in an interactive way by some kitsch characters while they were entering the hall (Snow-white and pirate characters offered cologne and candies at the door to the viewers, the wizard character chatted with the viewers by acting like telling fortune and doing magic). Later the performances prepared at drama class were staged in the company of music in a choreographic order. In the performance the first stage was given to kitsch characters (80 characters) who were not included in the improvisation group; later, the 3 selected kitsch improvisations ( 28 students in the improvisations titled wedding, bus and family) met with the audience on stage.

6) At the end of the study, all students who participated in the study prepared a file (portfolio) on the characters they portrayed. In this portfolio, there were photograph of the kitsch characters and questions as to why they chose this character, what the kitsch features of the character were reasons, how the character could have obtained these kitsch features, where and in which time period the character lived, and whether they felt uncomfortable about the character. Students were also asked to include their body-shot photos in the file which they think is not kitsch into their files and give examples to explain why they think it is not kitsch along with reasons. Finally, they were asked to explain what kind of impact their activities about kitsch had on them and their feelings and opinions on the topic. After all these studies conducted in class, interview method was used to gather the student opinions on kitsch phenomenon. In this context, this research can be defined as a qualitative study. In this study which employed qualitative research design, performances and videos created by the students, exhibition and interview method (as document analysis) were used as data collection technique. These data were descriptively analysed in the context of kitsch phenomenon and creativity concept.

\subsection{Study Group}

This study was carried out with sophomore students at pre-school teaching department. The study group of 38 students from 108 students who had taken courses of "Development of Creativity" and "Drama" was selected as a sample. Most students participating in the study were middle and low-income level students who came to Northern Cyprus from Turkey (mainly from Eastern, Southwestern Anatolia, and Central Anatolia regions) who 
received scholarship from their university or other institutions. Other students were receiving full scholarship that lived mostly in rural areas of Northern Cyprus. As situations permitted, at least one student from the groups created during classes was included in the study. In addition, as the number of male students in pre-school teaching department is low, researcher tried to reach all male students, but only 9 male students who accepted to participate voluntarily were included in the sample. In this context, "maximum diversity" sampling, one of the purpose sampling methods, was used in the study. The purpose of using this sampling method is to "maximize the diversity of the individuals who may be involved in the study for the problem under examination in the study" (Yıldırım \& Şimşek, 2016). As a result, the study group consisted of 8 male and 30 female students making up a total sample of 38 students.

\subsection{Data Collection Instruments}

A semi-structured interview form consisting of 10 questions was developed in the study. The questions on the interview were created based on the activities were mentioned in the design of the study section. Then, the views of two experts one from curriculum and instruction field and one from arts education on the interview questions were obtained. After receiving expert opinions, pilot study was conducted with one female and one male student. At the end of pilot study, the necessary revisions were made on the interview form. During the interviews, the students were asked in the beginning of Creativity and its Development class questions about their opinions on creativity, opinions on gaining awareness about kitsch phenomenon, their studies on kitsch concept; in the Drama class they were asked to provide the kitsch characters they created, evaluation of kitsch phenomenon from the viewpoint of children, their opinions on the concept of taste, the feelings they experienced on their performance day and a general evaluation of their studies.

\subsection{Data Collection Procedures and Analysis}

Interviews were conducted in classrooms and in the office of the lecturer. Informed consents of all students were obtained for voice recording of the interviews. The interviews lasted 20-25 minutes on average. Data obtained at the end of interviews were transcribed for every participant. Descriptive analysis" technique was used to analyse the transcribed data. The data were analysed based on the common themes deduced by the researcher based on the relevant literature and the scope of each interview questions. For this purpose, the critical events from students' responses to each interview question were determined and coded under the relevant category. Direct quotes of students' responses were reported to represent each category in a clear way. In the narration of students' responses, each student was represented with $\mathrm{F}$ (female) or $\mathrm{M}$ (male) along with the numerical value attached for the particular student. For instance, F12 refers to $12^{\text {th }}$ female student.

\section{Findings}

Findings of the study are presented under the following categories respectively: "an overview of the concept of creativity" and "examination of kitsch objects: the process of preparing videos and exhibition materials" awareness of kitsch", "evaluation of studies conducted in classes", "evaluation of kitsch phenomenon for children", "feelings experienced on the performance day", and "opinions on the concept of taste". Findings were supported with the direct quotes of students' responses.

\subsection{An Overview of the Concept of Creativity}

In the beginning of the "creativity and its development" class, all students were asked to answer the question" what do you think creativity is?" and asked to create an object or formation that they thought was creative. All of the teacher candidates defined creativity as everything that is beautiful and things that are liked by everyone. None of the candidates expressed their view about originality. The formations they prepared as creative object etc. usually appear as the imitations of an object that they found on the Internet and interpreted as beautiful.

The formations they prepared were: object from tie, rabbit from socks, drawing, story-writing, laptop from tray, game-closet design, lampshade from plastic forks, caterpillar from plastic bottle caps, maracas from plastic bottle, mirror framework ornament, sculpture from fork and spoon, heart-shaped pillow with flag figure, poem writing, making a bicycle from vegetables, vacuum cleaner from shoebox, penny bank and vase from plastic bottle, candleholder, line-drawing, pencil case from cans, fruit-shaped candle, helium balloon from light bulb, mirror from tray, vase from hand and foot moulds, train from cardboard box, speaker made of cardboard cups and water bottles, eye-drop distiller, paper mask, tea-box camera, foot shape made of stones, flying balloon from bulb or imitation of any object that they found on the Internet.

Following up the discussion on meaning of the creativity and Kitsch concept and creative object formation activity, the students were asked "whether they still found these works creative and whether these formations included kitsch elements" in the interview. Thirty-two of the students stated that they did not find the formations they made creative anymore and they understood that their works had kitsch elements. One of the students who shared this view stated her opinion as follows: 
F28. As an object I had made a flying balloon. It appeared to me that using waste materials as a different object was creative. But now I think that the object is sheer kitsch as I used completely exaggerated and unnecessary ornaments. And, since I used ready materials when using material, I think that the thing I made is kitsch.

Six of the students stated that their work was still creative and their formation did not include too many kitsch elements. One of the students who defended this view expressed his opinions as follows:

M5. I had designed an eye drop distiller. I aimed at ensuring that people with eye disorders can distil their eye drops more easily. For me creativity is free thought and doing something which had not been done before. Not hitting the road by looking at something, it is reaching somewhere with one's own ideas. I think creativity briefly means being free. I still think that what I did is creative as I did not see such a thing before and I think it is useful. It does not have any commercial goals. For this reason, I do not think it is kitsch.

Four of the students stated that the object and formation they produced was creative but they thought that it could include some kitsch elements in terms of material and feeling. Two of these students explained their opinions as follows:

F6. I made a wardrobe and wrote games on the back side of the clothes so that children could choose among games and play what they wanted. I had not seen it before elsewhere. I wanted a game closet when I was young; I made it like it. I thought how I could use it in pre-school. The games were written by me. But I used too many kitsch elements as material.

K3. I drew a picture. I drew what came to my mind. I think that it is creative because it was different from normal pictures. It brought together non-complying things. It did not have any kitsch aspect; I think it was creative.

\subsection{Examination of Kitsch Objects: The Process of Preparing Videos and Exhibition Materials}

Students examined the kitsches around them in "creativity and its development" course. The examined kitsches are related with fashion, architecture, external decoration, house furniture, accessories, jewellery, signboards, superstition and attitudes. Students worked in groups consisting of maximum 5 students. They produced short kitsch videos which included the kitsches they researched and photographed. Within the framework of creativity project, the students finally prepared a portfolio and exhibition materials. In the study, 15 exhibition materials were prepared about kitsch which were "superstition chest", lampshade titled "girl with skirt", a snail-shaped box, a shoe-shaped box, kitsch house model, nail catalogue, gift package box, jewellery box, curtain box, fashion magazine titled "kılık", kitsch kindergarten model, a fashion magazine in the shape of bag, a fashion magazine titled "Kiço" and a child photograph album. Since, three groups worked on the attitude kitsches, they prepared three videos named "crazy boy Iso", "teen room" and "neighbourhood" which emphasized superstitious beliefs.

The video that the students prepared in the fall semester was watched together with these students during the interview and they were asked to provide details on which kitsch materials they used while preparing this video, whether they reached the materials they needed as regards the topic of the video, and if they had the opportunity to produce the video again which elements they would add or omit. Eleven of the students stated that they were satisfied with their work and did not want to add or omit any elements. Students explained that if they used arabesque music in their video they could have put more emphasis on the kitsch phenomenon in their work, that if they used a kitsch house in their video and they were also in the video, it could be better, that if they could produce the video again they would like to add more kitsch elements, that as they are more knowledgeable about kitsch, they could use kitsch elements more carefully, which they did not. Ten students who produced videos about behaviours explained that they could add more kitsch to the live characters they used in their videos, some objects could be omitted form the video, it would be more striking if they added a male character dressed in woman clothes, they could have produced better videos if there was not time constraints, their videos were produced amateurishly and if they could have added different kitsches to their study they could have produced more noticeable videos.

One student who worked on child kitsches in the study explained his work as follows:

F12. I worked on child kitsches in the creativity project. I prepared an album on the dressing and accessories used by parents for children and I continued creativity class from this project. While preparing the project especially shiny pacifiers used by babies, room ornaments, baby clothes, objects which display sentences written by babies for their fathers, and kitsch baby rooms were included. My viewpoint towards baby clothes changed after this project, I started to see them differently. Then I designed an album consisting of child kitsches.

\subsection{Creating Kitsch Character in Drama Class}

In the interviews, students were asked to define kitsch concept. Students defined kitsch as mimesis, exaggeration, vulgarism, non-original, showing-off, degeneration, arabesque, not being self and resembling everyone else, 
wannabeism, unmannerliness, produced for commercial purposes without aesthetic concerns, cheesy, ratty, undeveloped form of tastes, lower-class practice, inconsistent with real meaning and far from creativity.

Students were asked the reason for which the character they created in drama class at spring semester was kitsch, how the character acquired kitsch features and what they felt when they adopted this character.

All students except two of them stated that they portrayed their roles with pleasure without feeling any discomfort, whereas two students explained that their discomfort continued until they wore the role and appeared before the audience, but during the performance they relaxed and enjoyed the role. Students in general explained the kitsch features of the character they portrayed as follows: exaggerated speeches, dressing just for fashion, portrayed character is a degenerated elderly person, spoiled behaviours, humiliating and overlooking others, showing involuntary behaviours, gossiping, speech and jewellery, a shouting and yelling, too clamorous child, clothes, make-up and used accessories, emulating the rich people who portray the legendary character, interest in fortune-telling, emulating the environment, imitating accent, flatulency, and identical imitation, which is why the characters they portrayed were kitsch.

Two of the students expressed their opinions on this issue as follows:

M2. As we know I was a bus driver. I usually observe this character in natural life, too. As I am observant, thus I thought that I could portray this character more easily. I tried to reflect being kitsch with hair style, dressing style and behaviours. The kitsch features of my character may be influenced by the culture and society and the job as well. He may be doing these behaviours by seeing others. Maybe he made observation just like I did. I had been interested in being a bus driver since I was a child but I could not do it. For this reason, I enjoyed my role and did not feel uncomfortable about it. Since, you want to do things in daily life but cannot do and drama gives you the opportunity to realize these things. With this character I could easily appear before people the way with this character, I could comfortably exhibit what I wanted to do in front of people as I wanted.

M4. The groom character I portrayed was a character who did not think anything original. He was a character who followed the actions and discourses of everyone. On the other hand, if you do something marginal it does not fit our culture. You have a marginal wedding and in the end your mother in law comes and extends her hand so that you can kiss, and unfortunately everyone becomes a part of this wheel. When I adopted this character, I made a rehearsal of a beautiful thing, founding a home for myself. I did not feel uncomfortable with my character because he was extremely typical, when you look at the grooms around the framework is determined, you cannot change it. I was somewhat winced with the fact that I would be trapped in stereotypes just like the person here.

The reasons for which the characters portrayed by students adopted their kitsch features were explained as not being able to endure fame, parents, being unable to leave the neighbourhood due to the fear of neighbourhood pressure, environmental factors, social media and technology, behaviour erosion caused by our age, fear of being excluded from the environment, wannabeism, behaviours of the mother, attracting attention of children, character having origins in the student himself, from family, wannabeism for rich people and environment, doctrines, family, due to an impulse coming from within, acting femininely in order to appear elder, migration from rural to urban areas, disobeying parents and the environment, being spoiled by parents, being unable to think originally, in order to eliminate parent pressure and become rich quickly, the will to show that he/she has what everyone else has.

Three of the students expressed their opinions on this topic as follows:

F13. I played the role of a hairdresser in the drama class. My character migrated to Istanbul from Urfa. She wanted to become a hairdresser and found friends that were suitable for her. When she began working at hairdresser, she began to imitate what she saw in her environment. I was uncomfortable with my character in the beginning but later I began to like her. She was a closed person in her hometown because the environment required it. She was wearing a headscarf just like me. When she came to large town, she began to attract attention with different styles as she could not open completely by making changes in headscarf, trying to change her speech and outfits etc.

F4. My character was a university student. She somewhat had a behaviour problem which was the result of the present days. I think that she was kitsch because of the reactions she showed to events, her exaggerated reactions which are more than what should be and also since, she did not care about anyone.

F11. I was a character who was born and raised in Istanbul. I was a metropolitan child. I was raised rich and very spoiled. I did not play a role in my own gender. To begin with, since I portrayed a male character, it was itself kitsch. I did not feel uncomfortable with my role. Only his disrespect for an old person made me uncomfortable. I was a university student just like that character and I did not find my role odd as some of my male friends around me gave similar reactions. 
When the opinions of students were asked as regards the character they portrayed in the interviews, except nine students all of them indicated that there was nothing they wanted to add to the character they created and that their roles were settled. Two of the students who were happy with their role expressed their feelings and opinions as follows:

F28. I was very happy with my role. My character settled. I understood that I took adopting that role very simple in the beginning. I did some research in order to make sure that the character settles. I collected materials. I spared special time for my character.

M7. My character settled. In the beginning I thought a one-legged pirate but they I thought that it was impossible for me to walk in the ceremony like that.

Three of the students who wanted to add some elements to their role said that they wanted to make additions related to the appearance of their character. Two of these students told that they understood that they could make kitsch elements more prominent with make-up whereas one students confessed that he did not think of using fake nails in order to make the little red riding hood role more kitsch, one student told that she wanted to see the character she portrayed as a more media-popular person, another student said that he wanted to add more dancing figures to his role, one person said that although he could add accent to his role, he was prevented by his peers due to concerns about using time economically, two students said that the length of their role made their character passive but they could not think of it while accepting their roles, and one person said that he wanted to add more squabble to his role.

\subsection{Awareness of Kitsch}

The students interviewed were asked whether they thought that there was a change in their kitsch issue in their lives Students who told that they gained awareness about kitsch and underwent change claimed that there was change in their lives and they began to approach the kitsches in their lives more carefully. Thus, they indicated that they began to find many kitsches in their wardrobe although they thought they were simple people before. In addition to this; they began to view their environment through critical eyes and understood that beauty could be reached without exaggeration. They started to act more carefully at school as everyone in their class knew the concept of kitsch that they understood kitsch well and were clarified from kitsch that they tried to become simple. Another interesting thing striking to see for the students was that the things they bought with fancy were kitsch. After the study, they stated that they could see the kitsches around them quickly, that they realised that they were kitsch all by themselves that they no more preferred things that everyone had, that their kitsch attitudes began to be healed, that they paid attention to uniqueness. Finally, they noticed the kitsches in their lives and tried to raise awareness in people around them, and that they began to think more aesthetically. Except three students all of the students expressed that their awareness about kitsch phenomenon increased and they noticed the change in their lives in a striking manner that it was difficult to stay away from this concept in this present era but they tried to be distant from it as far as possible. Four of the students who said that they gained awareness about kitsch expressed their opinions as follows:

F27. My perspective changed as kitsch. I saw that internalizing a concept and living is not the same as looking at its definition from outside. Even in our behaviours we often have kitsch. The best example for this is we all follow the fashion. We imitate something that everyone else wears. I do that too.

F29. There has been a complete change. If you pay attention you can see that there is no makeup on my face. Ends of my hair were dyed, and I cut them off. I began to use less makeup. While choosing dresses I can say "this is too kitsch" or "she dresses so kitsch" which I did not say before. While combining the pieces I am paying attention to make sure that they are more suitable for me. I began to stay away and not follow fashion. I am paying attention to make sure that it is unique to me.

F30. Learning kitsch made me see my life from a broader perspective. Because, I was a very kitsch wearing person, that is what I saw. Looking from the view of society we are ensuring that our community learns it, too. I am also telling my friends. And, because the name is very different, it attracts attention and stimulates learning.

M4. I think I learned kitsch. You have to be a unique individual because I will become a teacher, I will enlighten the new generation. Then, if we want our children to be productive, and want them to be creative, we have to begin from ourselves. And I will ensure this by staying away from kitsch elements, imitations, and being creative.

Three of the students explained that although they learned kitsch concept very well, they loved being kitsch and expressed their opinions on this subject as follows:

F3. Actually, although I understood kitsch concept very well, no change happened in myself. I love ornaments and showing-off. Now kitsch is a part of my life, I cannot take it out. Nobody has simplicity in their lives. It is a part of the age.

Two students stated that they had confusion about their awareness on the concept of kitsch:

F6. I can answer this question both as yes and no. 
first of all, I am paying attention to kitsch now. Secondly, I think that it is not possible to avoid this concept.

F21. When I see something with leopard patterns I still like it. Maybe as I look very young, I am choosing objects which show me older. Although I look like a child, I feel myself older and that is why I am choosing leopard-pattern things. Maybe I am doing it to show people that I am old enough, I am not as young as they think.

\subsection{Evaluation of the Activities Carried out in Courses}

To the questions "how do you evaluate the works created in "creativity and its development" and "drama" courses in general?", "Is it necessary to emphasise the subject of kitsch in studies conducted on creativity?", "Do you think that the concept of kitsch is effective in understanding creativity?" and "what would you recommend make the classes more effective?" asked. The students answered that they did not know what kind of a process they would experience in the beginning and therefore, they had difficulty in preparing creative projects, and that they were surprised to notice that what they saw as creativity were actually kitsch.

All students stated that the concept of kitsch was effective in understanding the concept of creativity and that these classes ensured group work, self-knowledge and socialization. Some students stated that they gained awareness on creativity through kitsch; some others claimed that they gained personal knowledge through kitsch, developed awareness about education system and teacher education. Majority of the students $(\mathrm{n}=$ ???) indicated self-evaluation and awareness about creativity in arts education, other students indicated knowledge and awareness about kitsch had increased; some mentioned awareness about popular culture, some talked about the necessity of arts education, and some others talked about personal self-awareness. Three of the students expressed their opinions on this subject as follows:

M7. I believe that kitsch concept definitely influence the understating of creativity concept as an individual who does not fully understand creativity can comprehend it better with its opposite, which is kitsch. I think that one person gaining self-confidence, getting rid of his stereotypes, beating his fears is the best thing that could be achieved in such a short period of time. When we learn what creativity is not, we learn what creativity is.

F12. First of all, I did not know anything about kitsch. I learned what it is in creativity class. The concept of kitsch attracted my attention for presenting uncommon opinions not in uncommon ways but in the form of common products which do not bear any aesthetic concern. Creativity is truly and essential concept. It is very important for the development of a country. I think that a country has to generate unique and creative ideas so as to be elevated to the level of contemporary societies. After learning the concept of kitsch I think that I can better understand how to perceive creativity.

F6. I think that this concept definitely be introduced and all pre-school candidate teachers should see this concept because we sometimes resort to exaggeration. We want everything to be too fancy. We try to sugar the pill for parents in that way. I think, in our last activity, we internalised the concept. I think, we had a very good semester.

\subsection{Evaluation of Kitsch Phenomenon for Children}

The students were asked to evaluate the kitsch phenomenon for children. Most of the interviewees stated that kitsch phenomenon was objectionable for children. The students who believed that kitsch was objectionable for children claimed that growing by imitating their environment is detrimental for the development of the child, that mimesis and exaggeration would harm children, that one has to be the right model for children, that they have to perform more creative activities, that social media affected the child imagination negatively, that children could create different characters by using power of their imagination instead of acting like cartoon characters, that children are given a wrong perception that showing-off is an important thing and it was detrimental as it killed creativity, that it prevented children from being more creative and simple, that unfortunately parents and pre-school teachers reinforced kitsch concept through their studies and turned their children into kitsch without knowing it and moved them away from naturalness, that dressing little girls as women and applying making-up was very objectionable and that children could not live their childhood, that children learned consumption with this concept, that the drawbacks of this concept should be taught at early ages, otherwise, it would not be possible to avoid this concept.

Three of the students who evaluated the concept of kitsch as objectionable for children expressed their opinions as follows:

F2. Actually, children are not knowledgeable in this subject. Parents take their children to somewhere and order them something to eat. Children do not have to do much as they just do what they are told. The biggest task is on parents again. The duty of parents may be keeping their children away from kitsches, artificial things, mimesis and exaggerations around them from the moment they are born and making sure that their children lead a more realistic and natural life.

F19. When we look at the kitsch concept from children' perspective, I think that it is objectionable. 
When the child comes to us, if he does not do something flamboyant, we are turning our heads since it is not flamboyant. When it is flamboyant, elegant, fancy, and when it appeals to the eye, we teach the child the importance and prominence of showing-off. When we act like this, the child thinks that to do something good, it has to be flamboyant and mimetic.

M4. I think that children have to be kept away from this phenomenon. As technology advances a new kitsch begins. Every child has to move away from their PDAs (personal digital assistant) and tablets and generate his own game.

Two students stated that this concept had both beneficial and harmful aspects, one indicated that she did not think it was harmful, and the other one stated that the child would not have any problems as he did not know the concept, two claimed that although the concept had harmful effects on the child it should be given without exerting pressure on him. One student who thought that it did not cause any harm to the child expressed her opinions as follows:

F16. Actually, I do not think that kitsch phenomenon is harmful for children as we also were grown in this phenomenon. We did not know that leopard patterns and visiting a fortune teller were kitsch. We all have accepted this issue. We have grown up that way; I do not think it is harmful.

That student was asked the question of" then what kind of role model we should be for the child?" The answer given by the student is as follows:

F16: We must be someone who does not resemble everyone, is unique, has unique opinions and we must show that we are not walking with the ideas of others and that we are an individual belonging to ourselves.

\subsection{Emotions Felt on the Performance Day}

The students were asked to evaluate their performance day that they experienced in the conference hall of the university. All students stated that the study conducted on performance day was very striking and awareness-raising for both themselves and the audience. They expressed that they were very excited on the day of performance for which reason they did not think that they would be so successful at the performance. Also, they indicated that they received very positive reactions from the audience, gained self-confidence, created awareness and questions in minds. They also stated that they raised curiosity, attracted attention in terms of creativity that they fussed as they thought they would not be understood but they were relaxed by the positive reactions from the audience. All students, except two of them, stated that they did not carry out a performance in front of the audience before. Yet, they indicated that with this study their self-confidence was improved. One student said that they worked too hard and were rewarded for their efforts, four students said that they served as a mirror, two students said that what they tried to do was understood, six student told that they enjoyed and entertained on the day of performance, one student said that when she thought about her performance day she still had a nice chilly feeling and in their limited environment such things should be done in terms of socialization and education. One student expressed his hopelessness by claiming that although awareness was created with this study people would not give up on kitsch. One student expressed her opinions as follows:

F2. Before the performance day, we were worried about if people would understand us. We were also worried if someone would feel resentful since we were doing things from daily life. During the performance people had fun. Because they saw something while they were having fun, we did this without anyone getting bored and without breaking anyone. I saw many people after the performance and they said that they had these things in their lives but did not think them from this perspective and thought that we held a mirror to them. I can say this with inner peace due to the reactions I received from people.

\subsection{Opinions on the Concept of Taste}

The students were asked the question of "Can taste be discussed?" In the beginning majority of them were abstaining to the opinion that taste could be discussed. Eighteen students who were abstaining about the discussion over taste said that tastes varied from one person to another. Also, they indicated that if people were shaped tastes, it can and should be discussed. However, in order not to hurt other people, they abstain from discussion, they thought that taste should be given without insulting others, taste education should be given in childhood and only then it can be discussed, that in order to develop taste it should be explained well, and tastes can be discussed only with very close people. They also stated that discussing tastes was difficult and as the case in kitsch study it should be given without offending anyone. Also, they thought, changing the opinions of people was very difficult and people were prejudiced, and liking was personal and people should be taught to abstain from mimesis and exaggeration. In addition, taste could be given by communicating and discussing with people because this method has worked on herself. Although her dressing style was not liked by people around her, she liked that style. Two of the students who agreed with this perspective also expressed their opinions as follows:

F15. Taste is everyone doing what they like. Taking 
away something natural from its reality is killing the creativity of people. Everyone can like different colours but people must also learn kitsch. After all, I think that nothing should be taken away from its naturalness.

F16. Changing taste is difficult. In order to teach taste, it should be first taught that everyone has different tastes and there are differences and then we can explain.

Two students said that tastes could not be discussed. One of the students expressed her opinion as follows:

F22. I think that tastes cannot be discussed. But I do not think it could be a problem if you are with people who have developed themselves. For example, in our study, we did not tease about any characteristic of any one in general, we paid attention to that. If we did not do it that way people could feel offended.

Seventeen students who thought that tastes should be discussed stated that people could only think on things that they discussed, that one should be honest towards people, tastes should be interfered with, that vulgar things which offend the eye should not be done, that they gave a tacit message to people and thus they discusses tastes, and that discussion was necessary so that naturalness could be conserved, whereas one student said that he could talk about his tastes without any hesitation, one student said that honesty was always necessary towards people, and two students told that with this study they tested whether they were able to sit and talk about this concept and do critics.

Two students who stated that tastes should be discussed expressed their feelings and opinions as follows:

F19. I think that tastes can be discussed. I tell my opinions directly so that it can be better. I think that one should be honest and open towards people.

F30. I think that tastes of people can be changed through discussion and verbal communication as fads can change. For example, with this study I am a different person from the past.

\section{Discussion, Conclusions and Suggestions}

The examination of this study finding shows that in the beginning of the study the students thought that every mimetic object which are liked and product of popular culture was creative without subjecting them to critical thinking. Güven [13] claims that the leading social movement which is the source of emergence of kitsch phenomenon was migration from rural to urban areas and ghettoization of cities. Acartürk [27] states that the taste measures that people migrating to cities brought with them experienced change but this change was mutual meaning that they also affected and changed the artistic tastes and habits of the city. This change affected all segments of society. It is also important not to overlook the fact that the students in the study are children and grandchildren of these families.

In this context, after the kitsch phenomenon examined in "creativity and its development" and "drama" courses and all the works and activities completed related to kitsch, the students were asked to share their initial thoughts on creativity and whether they still found creative the individual works that they thought were creative. Except three students, all of them indicated that they no more found the formations they made as objects in the beginning of the study as creative and they questioned the concept of creativity with kitsch concept, as a result of which they gained artistic awareness. Considering that the students who participated in the study had not received any education as regards arts education before, it can be said that the obtained result is striking. With this finding, it can be said that the studies to be conducted for the artistic development of the individual are meaningful when they are excluded from the traditional teaching models and studies carried out mainly in theory.

That individual can notice creative studies, evaluate the difference between a work of art and a replica, take notice of the concept of aesthetics displays the importance of studies related to art and arts education programmes. For this reason, it is important to develop the artistic awareness of teacher candidates and educate them with artistic consciousness. Dinçer, Demiriz and Şimşek [28] emphasize that innovation, originality, difference, in short, creativity is sought in every work done today, and that our growing children and generations should meet these concepts and their education should be reinforced with these concepts. While talking about art education, Erbay [29] states that education is a production, and that the individual needs to be able to produce what is good and right, as well as to be able to choose quality and aesthetics. As soon as art education is given at an early age, the social deformation in this subject can be lifted so quickly. For this reason, the right education which will be given to the young people who did not receive this education that should have been received at early ages can reveal their artistic views even if they are adults. This situation can mean that they will spend the rest of their lives nested with art, and although "kitsch" does not mean they will not use any elements, it can mean that they will gain artistic awareness.

The most challenging process of the study from the viewpoint of the researcher was ensuring that students see the kitsch concept that encompasses so much of the lives of students, with a critical perspective. For this reason, attention was paid to make sure that the study, which was realised as a procession study, was entertaining. Students involved in this process began to take notice of the 
kitsches around them. In this awareness process, they were sometimes alienated from the concept that encompasses their lives completely and did not feel any disturbance about the concept. Yapıc1 [30] states that rapid urbanization and change in living conditions caused people to become alienated to the culture and themselves as an individual, which is the result of the efforts to make people monotypic. For this reason, the process of understanding by the people participated in the study that they are "standardized" took so long. The studies they conducted and videos they produced during the semester were watched again with each student during the interviews and they were asked to tell what were the kitsch materials they used, whether they could reach the materials related to their video topic and which elements they would they add or eliminate if they were given the chance to produce the video with kitsch theme again. Most students told that their understanding of the kitsches process developed in time; thus, although they could choose the kitsches they studied in a more striking manner, there were some deficiencies in the producing process of these videos. This shows that artistic development of an individual requires a long period.

It is important to remember that our descendants whom we have removed from creativity and standardized are our children. In this context, students were asked whether kitsch phenomenon was detrimental for children. Most of the students stated that kitsch phenomenon was detrimental for children, moved them away from naturalness, taught them consumerism, made them monotypic at early ages and weakened their imaginary power, removing them from naturalness and creativity. They also argued that parents had to be knowledgeable about his subject and set accurate role models, that television and social media, cartoon characters increased mimesis, and that teacher should conduct studies which are far from mimesis. The fact that many participants think this way suggests that it is possible to internalize this concept by carrying out studies involving doing and living. It can be said that the applications performed in this study and the process experienced made this possible. Baudrilland's [4] expression "at all levels of society, the next generations follow their own show-off objects" display the importance of the concerns of students that "the detriments of kitsch concept should be taught at early ages, otherwise one cannot move away from this concept". Only one of these students stated that kitsch phenomenon was not detrimental for children since kitsch was accepted by everyone. The reason for which she thought that it was not detrimental maybe that she was grown up in a kitsch environment just like everyone else and she felt that she would contradict with herself if she said "it is detrimental for children", as when the same student was asked "what kind of a role model should be set for the children as adults?" she gave an answer which reflects the purpose of this study. The student answered that "we must be a unique individual who does not look like everyone else" and displayed her contradiction in a very striking manner. When the kitsch phenomenon is examined from the viewpoint of children, it can be said that studies which include "kitsch" elements far from creativity affect the entire life of the child who does not meet artistic stimulants. It can be interpreted that children who are standardized and whose imaginary power is weakened at early ages move away from naturalness and creativity which has its reflections in other stages of education. For this reason, students expressed that when the subject "kitsch" was being covered in" creativity and its development" and "drama" courses, they were surprised to see that what they saw as creative were actually kitsch. In order to prevent this contradiction, it is very critical that the education which will be given in childhood is supported with classes which will increase aesthetic awareness and creative studies in these classes.

When the teacher candidates were asked "can tastes be disputed?" majority of them provided an abstaining stance in the beginning on the disputability of tastes. Tunal1 [6] commented on tastes that saying that every taste is right and legitimate cannot be debated on aesthetic judgments, which leads to a scepticism on aesthetic values and explains that the reason for which the saying "Degustibus non est disputandum" (in matters of taste, there can be no disputes) is so much popular in societies is another topic of research. The answers obtained from interviewees support the discourses of Tunalı. Students stated that they could share their opinions on "tastes" only with people they are close with, that it is difficult to change tastes, that the society is not open to criticism, that tastes should be debated but generally they hesitate to explain their real opinions, and if it is to be explained, it has to be explained without offending or hurting anyone. Although these opinions of students can be unfamiliar to societies which are open to criticism, being able to criticize brings the importance of thinking and questioning with it.

Based on the findings of the study, teacher candidates thought that the kitsch concept which was covered in "creativity and its development" and "drama" courses was effective in understanding creativity. The reason of this perception is that with the study they were able to see the elements far from creativity in a striking manner and that drama in education helps them in seeing the kitsch phenomenon through critical eyes. Teacher candidates explained that with this study, they gained awareness about the "kitsch" concept which they had never heard of before and began to notice that when they move away from simplicity and aesthetic. Also, they realized that they quit being themselves and resemble others and become more kitsch. This may be the reason why a teacher candidate who is aware of this will be more sensitive in educating creative individuals.

Although it is not known that the education system, educational policies, school-family co-operation must be a 
whole in order to cultivate creative individuals, the greatest responsibility in this regard rests on the educators. In every stage of education life, there is need for educators who understand, tell and practice creativity accurately, which begins with pre-school education. It is essential that teachers who provide this first education to the child have to take the road with the purpose of educating creative individuals. It is critical for accurate understanding of creativity that the programmes applied to the individuals being educated at teaching departments of universities pay attention to creativity concept. For this reason, raising awareness on creativity through courses such as "creativity and its development", "drama", "arts education" at college of education in universities, providing the necessary environment and ensuring that experts on arts deliver courses will be meaningful and improving for teacher candidates.

\section{REFERENCES}

[1] Şahin, H. (2016). Sanatta kitsch olgusu üzerine. Akdeniz sanat dergisi, 9 (17). 1-27.

http://akdeniz.dergipark.gov.tr/download/article-file/16674 6 adresinden erişildi.

[2] Fisher, R ve Williams, M. (2004). Unlocking creativity teaching across the curriculum. London: Routledge.

[3] Özdemir, F ve Koca, B. (2013). Makine olarak Andy Warhol. Ídil sanat ve dil dergisi, 2 (6), 239-253. http://www.idildergisi.com/makale/pdf/1357559472.pdf adresinden erişildi.

[4] Baudrillard (2016). Tüketim toplumu. Söylenceleri/ yapılart (8. bs.). İstanbul: Ayrıntı Yayınları.

[5] Ergin, Halhalli. H. K. (2013). Hakikatin iptali ya da çirkinliğin meşrulaşması olarak kitsch pratikler. Inönü Üniversitesi Sanat ve Tasarım Dergisi, 3 (8), 189-196. http://dergipark.gov.tr/download/article-file/92488 adresinden erişildi.

[6] Tunalı, İ. (2011). Estetik beğeni.Çağdaş sanat felsefesi üzerine. Ankara: Remzi Kitabevi.

[7] Şaylan,G. ( 2016). Postmodernizm. (5. bs.). Ankara: İmge Kitabevi.

[8] Kulka,T. (2014). Kitsch ve sanat. (G. Gülbey, Çev.). İstanbul: Altıkırkbeş Publications.

[9] Erinç, S. M. (2009). Sanat sosyolojisine giriş. (1. bs.). Ankara: Ütopya Yayınları.

[10] Berk, E. (2017). Halk zevki ve zevksizlik arasında: Bir kitsch sosyolojisine doğru. Ulakbilge, 5 (14). 1205-1226.

[11] Tuv, J.O. (2010). Kitsch'i savunmak. (A. F. Korur, Çev.) İn Odd Nerdrum. (Ed.), Kitsch üzerine, İstanbul: Mitos-Boyut Yayınları.

[12] İlkyaz,A. (2015). Çağdaş sanatın çıkmaz sokağı: Kitsch'in zaferi. Aydın Sanat İstanbul Aydın Üniversitesi, Güzel
Sanatlar Fakültesi Dergisi yayınları.1(1), 1-10. İstanbul.

[13] Güven, M. (2016). Sanat eğitimine eleștirel pedagoji bağlamında kitsch olgusu ve estetik beğeni üzerine bir değerlendirilme. Yayınlanmamıș doktora tezi, Dokuz Eylül üniversitesi eğitim bilimleri enstitüsü güzel sanatlar eğitimi anabilimdalı resim-iş öğretmenliği programı, İzmir.

[14] Akçum, E. (2005). 5-6 yas çocuklarının yaratıcılık ve öğrenime hazır oluş düzeylerine okul öncesi eğitimin etkisinin incelenmesi. Yayınlanmamış yüksek lisans tezi, Selçuk Üniversitesi,

Konya.http://ulakbilge.com/makale/pdf/1499019815.pdf adresinden erişildi.

[15] Craft, A. (2002). Creativity and Early Years Education. A lifewide Foundation. London: Continuum.

[16] Kalburan, N.C. (2011). Erken çocukluk eğitiminde yaratıcılık ve sanat. Ankara: Eğiten Kitap.

[17] Kırışoğlu, O. T. (2015). Sanat kültür ve yaratıcılık. Ankara: Pegem Akademi Yayınevi.

[18] Terwiel, Dizdar, C. (2010). Okul öncesi sanat eğitiminde bir malzeme olarak "kil"in yeri. e-kitap Ankara: Üniversitesi Rektörlüğü Yayınları. No: 258. http://kitaplar.ankara.edu.tr/dosyalar/ pdf/826.pdf. Erişim Tarihi: 10. 06. 2017

[19] Sebik, C. (2012). Sanat eğitiminde bir estetik problem olarak kitsch ve sanat ayırımı. Yayınlanmamış yüksek lisans tezi, Dokuz Eylül üniversitesi eğitim bilimleri enstitüsü güzel sanatlar eğitimi ana bilim dalı resim iş öğretmenliği programı, İzmir.

[20] Çankaya, İ. Yeşilyurt, E. Yörük, S ve Şanlı, Ö. (2012). Öğretmen adaylarında yaratıcı düşünmenin yordayıcısı olarak değişime açıklık ve hayal gücü. Uşak Universitesi Sosyal Bilimler Dergisi, 5 (2), 46-62.

[21] Gökalp, M. (2016). Cocukta yaratıcılık ve yaratıcı çocuk etkinliklerinin "Yaratıcılık ve Geliştirilmesi" dersinde okul öncesi bölümü öğrencilerine olan etkisi (Samsun eğitim fakültesi örneği). Manas Sosyal Araştırmalar Dergisi. 5 (3).

[22] Y1lmaz, M. (2015). Toplumun sanat kültürünün biçimlenmesinde taklit, kopya ve şablon çalışmalarla yetişen nesillerin etkisi. Akdeniz sanat dergisi. 8 (15) 104-112.

[23] Lugg, C.A. (1998). Political kitsch and educational policy. Paper presented at the AERA Annual Convention, San Diego, CA.

[24] Mamur. N. (2012) Kitsch (Kiç) olgusunun sanat eğitiminde estetik beğeniler açısından sorgulanması. Mersin Üniversitesi Eğitim Fakültesi Dergisi, 8 (3), 70-79.

[25] Dikici, A. (2013). Yaratıcılığı destekleyen ilköğretim öğretmenleri indeksi ölçeği'nin türkçeye uyarlanması. Kuram ve Uygulamada Eğitim Bilimleri Dergisi, http://www.kuyeb.com/pdf/tr/84bdea521b4805ee382f6539 7eaf0e4407324.pdf adresinden erişildi.

[26] Akar, Vural, R ve Sommers, J. (2016). Illkögrretimde drama: Kuram ve uygulama (3. bs.). Ankara. Pegem Akademi Yayıncilik.

[27] Acartürk, B. (2009). Popüler kültürde kitsch olgusu ve seramik sanatına yansimaları. Yayınlanmamıș sanatta 
yeterlik tezi, Dokuz Eylül Üniversitesi, İzmir.

[28] Dinçer, Ç. Demiriz, S. ve Şimşek, I. (2003). Okul öncesi dönem çocuğu olan ebeveynlerin sanat eğitimine olan yaklaşımlarının incelenmesi. Ĕgitim ve Bilim Dergisi, 28 (129), 50-63.

[29] Erbay, M. (2013). Sanat ĕgitimi üzerine. İstanbul: Beta Yayınevi.
[30] Yapıc1, M. (2004). Eğitim ve yabancılaşma. Uluslararası insan bilimleri dergisi. 1(1). 1-9. https://www.j-humansciences.com/ojs/index.php/IJHS/arti cle/view/98/97 adresinden erişildi.

[31] Yıldırım, A. \& Şimşek, H. (2016). Sosyal bilimlerde nitel araştırma yöntemleri (16. Baskı). Ankara: Şeçkin Yayıncilik. 